\title{
Ownership Structure of Iranian Evidence and Payout Ratio
}

\author{
Seyed Jalal Sadeghi Sharif \\ $\mathrm{PhD}$, Assistant Professor \\ Management and Accounting Department, Shahid Beheshti University, Tehran, Iran \\ E-mail: Jsadeghi46@yahoo.com \\ Mahdi Salehi (Corresponding author) \\ PhD, Assistant Professor \\ Accounting and Management Department, Ferdowsi University of Mashhad, Iran \\ E-mail: Mahdi_salehi54@yahoo.com \\ Hojjat Bahadori \\ M.A Holder in Accounting Management and Accounting Department, Iran \\ E-mail: h_bahadori2007@yahoo.com
}

\begin{abstract}
The aim of this paper is to identify and analyses the influence of shareholder ownership identity on payout ratio for a panel of Iran firms from 2002 and 2008. We find that there is a significant positive correlation between institutional ownership and payout ratio. The relation between payout ratio and individual ownership is negative. The most finding of the study indicates that Iranian companies with highly concentrated ownership distribute more dividends. We show that there is a significantly positive correlation between the institutional ownership and the payout ratio. The relation between payout ratio and individual ownership is negative and the ownership concentration measured by the five largest shareholders affects positively on payout ratio.
\end{abstract}

Keywords: Ownership Structure, Payout Ratio, Earning Per Share, Dividing Per Share

\section{Introduction}

Firms can use internal or external sources to finance their investments. Internal sources include retained earnings and depreciation, while external sources basically refer to new borrowings or the issue of stock. Thus the financing decision involves the appraisal of two choices. The first is the dividend choice - the fraction of retained earnings to be ploughed back and the fraction to be paid out as dividends. The second is the capital structure choice - the fraction of external finance to be borrowed and the fraction to be raised in the form of new equity. On the face of it neither the dividend decision nor the capital structure decision should impact on the value of the firm. This is because both these decisions can be related to either the type of security, form of distribution, or make up of the ownership structure, but not to the investment decision. Thus the financing decision will determine the mix of debt and equity, the relative numbers of shareholders and debt holders, and the distribution of investment proceeds between interest, dividends and capital gains. Dividends and dividend policy were the subject of many studies for many years from past to present. Since dividends have an effect on stock prices and company's future growth, corporate governance should have a suitable dividend strategy. In practice, firms, managers, and investors devote much time and resources to making and analyzing financing decisions about dividends and capital structure. Corporate management needs to take different variables into account before taking the decision on the how and the when of dividend payout. Researchers follow different procedures to highlight factors expected to have some influence on dividend payout decisions and policies. Foremost of these determinants are level of profits, financing constraints, investment opportunities, size of the firm, and pressure from shareholders and regulatory authorities. One of the factors that can effects on dividend is ownership structure. Many authors argue that when large shareholders are firms, the manager distributes higher dividend than similar firms when their large shareholders are individuals. However, most of this empirical work has been focused on companies listed in markets of developed nations. Therefore the conclusions reached may not be applicable in countries with different corporate cultures and economic frameworks. 
The main purpose of this paper is to identify and analyze the influence of shareholder identity on payout ratio for a panel of Iran firms from 2002 and 2008. This country was chosen because it represents a different market with different features. This form of economy might require a special dividend policy that may differ from those used in developed or developing markets. Based on a sample of 41 listed companies on Tehran Stock Exchange (TSE), relationship between ownership structure and payout ratio will be discussed.

The rest of the paper proceeds as follows. Section 2 briefly reviews the ownership structure literature and related empirical work on dividend policy and payout ratio then investigates the research hypotheses. The model proposed in the study, definition of variables, sample selection, descriptive statistics and empirical regression results are provided in section 3. Conclusions end the paper in section 4 .

\section{Payout policy and ownership structure}

\subsection{Background literature}

Firms are generally free to select the level of dividend they wish to pay to holders of ordinary shares, although factors such as legal requirements, debt covenants and the availability of cash resources impose some limitations on this decision. It is thus not surprising that the empirical literature has recorded systematic variations in dividend behavior across firms, countries, time and type of dividend.

Fama and French (2001) bring evidence to show that dividend paying firms tend to be large and profitable, while non-payers are typically small, less profitable but with high investment opportunities.

La Porta et al., (2000) who studied the dividend policies of over 4000 firms from 33 countries around the world. It is found that dividend policies vary across legal regimes in a way that is consistent with the idea that dividend payment is the outcome of effective pressure by minority shareholders to limit agency behaviour. Thus firms in common law countries with good legal protection of investors tend to have higher payout ratios compared with firms in countries with weaker legal protection.

In other view, Lintner (1956) laid the foundation for the modern understanding of dividend policy. He interviewed managers from 28 companies and concluded that dividends are sticky, tied to long term sustainable earnings paid by mature companies, smoothed from year to year, and that manager's target a long-term payout ratio when determining dividend policy.

Kouki and Guizani (2009) find that there is a significantly negative correlation between the institutional ownership and dividend per share. They also found the ownership of the five largest shareholders, the higher the dividend payment.

Wiberg (2007) investigates the link between institutional ownership and dividend policy. Utilizing a dividend payout model, which accounts for earnings trends and partial adjustments, a positive relation, is found between institutional ownership and dividends.

Kumar (2003) studies examine the payout behavior of dividends and the association of ownership structure for Indian corporate firms over the period 1994-2000. He finds Institutional ownership has inverse effect on dividends in comparison to corporate ownership.

Using pooled cross-sectional observations from the top 50 listed Egyptian firms between 2003 and 2005, Abdelsalam, El-Masry, and Elsegini (2008) examined the effect of board of director composition and ownership structure on dividend policies in Egypt. It is found that there is a significant positive association between institutional ownership and firm performance, and both dividend decision and payout ratio. The results confirm that firms with a higher return on equity and a higher institutional ownership distribute higher levels of dividend.

By the construction of cash dividend decision model based on the protection of stockholders interest, $\mathrm{Li}$ and Huang (2004) use the data of Chinese manufacturing listed companies from 2001 to 2003 find that in China listed companies, institutional ownership has positive relation with the payout of cash dividends and this paper pointed that an effective way to deal with the current low cash dividend policy of China listed companies is to develop institutional investors and increase their stockholdings percentage.

Grinstein and Michaely (2003) examined the relation between institutional holdings and payout policy in U.S. public firms between 1980 and 1996. They find payout policy affects institutional holdings. Institutions avoid firms that do not pay any dividends. But among dividend paying firms, they prefer firms that pay fewer dividends. Their evidence indicates that institutions prefer firms that repurchase shares. They did not find that higher institutional holdings or a concentration of holdings causes firms to increase their dividends, their repurchases, or their total payout. Their results did not support models that predict that high dividends attract institutional clientele, or models that predict that institutions cause firms to increase payout. 
According to Harada and Nguyen (2003) investigating the effect of ownership on the dividend policy of Japanese firms. They find negative relationship between ownership concentration and payout rates. Firms with concentrated ownership are less likely to increase dividends when profitability increases and more likely to omit dividends when investment opportunities improve, which is consistent with extraction of private benefits at the expense of minority shareholders.

Gugler and Yurtoglu (2000) analyze 736 dividend change announcements in Germany over the period 1992 to 1998 and find significantly larger negative wealth effects in the order of two percentage points for companies where the ownership and control structure makes the expropriation of minority shareholders more likely than for other firms. They find larger holdings of the largest owner to reduce, while larger holdings of the second largest shareholder to increase the dividend pay-out ratio. Deviations from the one-share-one-vote rule due to pyramidal and cross-ownership structures are also associated with larger negative wealth effects and lower pay-out ratios. The presence of a second largest shareholder with a considerable equity stake makes a crucial difference in the governance of the firm.

Jain (2007) finds that individual investors prefer to invest in high dividend yield stocks and in dividend paying firms whereas, relatively lower-taxed, institutional investors tend to prefer low dividend yield stocks and non-paying firms. Consistent with Brennan and Thakors (1990) adverse selection model, informational superior institutional investors are shown to prefer firms that engage in larger share repurchases whereas individual investors do not prefer share repurchases. These results are contrary to the widely held beliefs (a) regarding tax-based and non-tax-based dividend clienteles, (b) that firms pay dividends to encourage monitoring by institutional investors, and (c) that the personal tax rate on equity is low (or zero).

Kafash (2008) studied the relation between the ownership structure and corporations performance for a panel of Tehran firms from 2000 and 2006. He consider 5 parameters for ownership structure: percentage of shares owned by the largest shareholder, institutional shareholders, individual shareholders, percentage of shares owned by the 5 largest shareholders, and percentage of shares owned by the board of directors. His data covered the time period between 2002 and 2006 on TSE. Using multivariate regression and t-students, he reached the conclusion among 5 variables; percentage of shares owned by the 5 largest shareholders, individual shareholders and board of director were not proven, percentage of shares owned by the large shareholder had linear negative effect on performance, but hypotheses about percentage of shares owned by the institutional shareholders had liner positive effect on performance.

Jahnkhany and Ghorbani (2004) studied factors determined the dividend policy of the Iranian companies. Their sample consisted 63 companies listed on TSE during a period of six years using statistical methods based on regression. They used "efficiency cash dividend" to reflect the dividend policy variable. Agency Theory, unlike the results of studies by Rozeff, (1982) in this research did not confirm. In the other way, ownership structure does not play a significant role in determining the dividend policy of the Iranian firms.

\subsection{Research hypotheses}

This section provides an overview of the hypotheses. To test the link between payout ratio and ownership structure, a set of four dummy variables were included to describe the ownership structure of the firm: largest shareholder (BIG), 5 largest shareholders (5BIG), institutional shareholders (INST), and individual shareholders (INDV). We propose that payout ratio is negatively related to BIG, 5BIG, INDV and positively to INST. Different firms have ownership pattern. Some firms have sponsors as the largest shareholders; some have institutional or managerial ownership as major. Different shareholders influence firm's dividend differently. So, ownership concentration and different ownership mix contribute differently to the firms' dividend and payout ratio. This may lead the following hypotheses:

Hypothesis 1: Largest shareholder ownership has a negative effect on payout ratio.

Hypothesis 2: 5largest shareholders ownership has a negative effect on payout ratio.

Hypothesis 3: Institutional shareholders ownership has a positive effect on payout ratio.

Hypothesis 4: Individual shareholders ownership has a negative effect on payout ratio.

\section{Methodology and Empirical Analysis}

\subsection{The Model Proposed and Definition of Variables}

Based on predictions of the finance theory and our earlier discussion, we consider the multiple linear regression equation described as follows:

$\mathrm{POR}_{\mathrm{it}}=\alpha_{0}+\mathrm{b}_{1} \mathrm{OS}_{\mathrm{it}}+\mathrm{b}_{2} \mathrm{E}_{\mathrm{it}}+\mathrm{b}_{3} \mathrm{SG}_{\mathrm{it}}+\mathrm{b}_{4} \mathrm{CS}_{\mathrm{it}}+\mathrm{e}_{\mathrm{it}}$ 
Where, $\alpha$ is the regression constant and $b_{1}, b_{2}, b_{3}$ and $b_{4}$ are regression coefficients respectively.

The dependent variable, POR is the Payout ratio. This variable is measured by divided dividend per share by the earning per share.

The independent variable Ownership Structure (OS) is defined as ownership structure. This variable includes four indexes were: percentage of shares owned by the largest shareholder (BIG), institutional shareholders (INST), individual shareholders (INDV), and percentage of shares owned by the 5 largest shareholders (5BIG). Our measure of ownership structure develops from Kafash (2008) study the relation between the ownership structure and the performance of corporations.

Earnings per Share (E) are a control variable that measures the profitability. This variable is measured by dividing net profit by the common stock.

Growth rate of sales (SG) is a control variable that measures by the annual change in the firm's total sales.

Size, CS, is a control variable that measures the size of the firm. It is measured by multiply the shares number of firms by market value of any shares. To summarize, the independent variables, their proxies, and the calculations are presented in Table 1.

\section{Insert Table 1}

\subsection{Sample Selection and Descriptive statistics}

This section describes (I) sample selection (ii) descriptive statistics and (iii) results of the regressions.

\section{Sample selection}

The sample was chosen from all Iranian firms listed on TSE for the period of $2002-2008$. As it is known that period of 5 to 6 years covers 2 business cycles. That is why period chosen is 2002-2008, which covers both recessionary and booming phase.

Data used in the analysis were collected from the annual reports documented on TSE. For all firms, our data set contains annual information on firm's payout ratio, ownership structure, and other firm specific characteristics. A firm must have data (on size, ownership structure, EPS, DPS) for March of year (fiscal year-end in March 20) to be in the sample for that year. We exclude investment firms and other financial firms because their financial reporting standards are different from those for the rest of the sample and have financial policies that are highly influenced by market conditions and investment companies. We also exclude the firms that changed the fiscal year. So, lastly there are 41 firms in our final sample, for which we have required data. Table 2 presents Sample firms by industry.

\section{Descriptive statistics}

Table 3 presents summary statistics of all variables used in the analysis. The table reports the range, mean, standard deviation, minimum, maximum and number of firms for each of the variables. The average payout ratio for TSE 41 firms for the years of 2002-2008 is 75.89 per cent. This means, on the average, firms pay about 75 percent of their profits as dividends. The averages of share ownership by largest shareholder, 5 largest shareholders, institutional shareholders and individual shareholders, are 46.67, 75.64, 79.96 and 8.24 per cent, respectively.

\section{Insert Table 3}

\subsection{Empirical Regression Results}

For the analysis of pooled data for seven years i.e. 2002 to 2008, first we used p-plot diagram and Kolmogrove-Smironove Test to test significance level of hypotheses. We used analysis of variance (ANOVA) and also used F Test and T-test to test coefficient of equations. The regressions analyses are conducted on four hypotheses:

Hypothesis $1:$ POR $=\mathrm{f}(\mathrm{BIG}, \mathrm{E}, \mathrm{SG}, \mathrm{CS})$

Hypothesis 2: POR $=\mathrm{f}(5 \mathrm{BIG}, \mathrm{E}, \mathrm{SG}, \mathrm{CS})$

Hypothesis 3: POR $=\mathrm{f}(\mathrm{INST}, \mathrm{E}, \mathrm{SG}, \mathrm{CS})$

Hypothesis 4: POR $=\mathrm{f}(\mathrm{INDV}, \mathrm{E}, \mathrm{SG}, \mathrm{CS})$

Table 4 presents the regression results for all hypotheses. The regression coefficient indicates the amount of change in the value of dependent variable for a unit change in independent variable. $\mathrm{R}^{2}$ the coefficient of determination, gives an estimate of the proportion of variance of dependent variable accounted for by the 
independent variable. It suggests the covariance between changes in dividend rate and earnings rate. The value of $\mathrm{R}^{2}$ varies between 0 and 1 . An $\mathrm{R}^{2}$ of zero means that the predictor accounts for none of the variability of $\mathrm{Y}$ by $\mathrm{X}$. An $\mathrm{R}^{2}$ of 1 means perfect prediction of $\mathrm{Y}$ by $\mathrm{X}$ and that $100 \%$ of variability of $\mathrm{Y}$ is accounted for by $\mathrm{X}$; the higher value of $\mathrm{R}^{2}$, The closer relationship between the variables.

The results show that Adjusted R2 of Hypotheses 2,3 and 4 are higher of zero and so relationship between variables almost are closer but Adjusted $\mathrm{R}^{2}$ of first hypothesis $\left(\mathrm{R}^{2}=0.088\right)$ is near to zero and so relationship between variables are not closer.

Then we examined the significance level of hypotheses. Results show that the significance of all hypotheses have the good significance level and are less than from $\alpha=0.05$, with the exception of first hypothesis ( ignificance $=0.120>0.05$ ). That is no significant correlation existing between percentage of shares owned by the largest shareholder and payout ratio.

Then we follow with t-test to examine relationship between the variables. As the t-test advocates, payout ratio is positively associated with institutional ownership ( $\mathrm{sig}=0.015)$. These results are consistent with the results of previous studies (see Wiberg, 2007; Abdelsalam et al., 2008; Qiang Li et al., 2004).

Contrary to our hypotheses, the results of this study surprisingly show a positive relationship between 5 largest shareholders ownership and payout ratio $(\mathrm{sig}=0.045)$. One explanation could be that more concentrated firms distributed more dividends. As expected, the results indicate a significantly negative relationship between payout ratio and individual ownership (coefficients $=-0.186$ ) and also support the hypotheses of negative associations between payout ratio and individual ownership. However, no significant association was found between largest shareholder ownership and payout ratio. The empirical results confirm the association between ownership structure and payout ratio in Iran.

\section{Insert Table 4}

\section{Conclusions}

This paper provides an empirical examination of the dividend policy in Iran. The major objective of this study is to identify the influence of ownership structure on the payout ratio. To reach this objective, we have used a sample of 41 firms over the period 2002- 2008. Our results suggest that ownership structure approach is highly relevant to an understanding of corporate dividends policy in Iran. We find that percentage of shares owned by the 5 largest shareholders and institutional shareholders have linear positive effect on payout ratio, but percentage of shares owned by the individual shareholders has linear negative effect on payout ratio. We find also that hypothesis about percentage of shares owned by the largest shareholder is not proven. Our findings indicate that dividend policy is not irrelevant as argued by Miller and Modigliani (1961). The results of this study generally support previous empirical studies. The implication of this article is that dividend payout policy decision of Iranian listed firms is influenced by the ownership structure of the firms.

Following from these findings, it would be useful to also consider the following directions for future research: Examining the influence of largest ownership, institutional ownership, individual ownership and 5 largest ownerships separately on dividend payout ratio.

\section{References}

Brennan and Thakors. (1990). A comparison of the market reaction to specially designated dividends and tender offer stock repurchases. Financial Management (Financial Management Association), Autumn, 1997 by Indudeep S. Chhachhi, Wallace N. Davidson, III.

Daniel Wiberg. (2007). Institutional Ownership and Dividends. Jönköping International Business School (JIBS), and Centre of Excellence for Science and Innovation Studies (CESIS), Royal Institute of Technology, Stockholm, 2007.

Fama, E.F. and K.R. French. (2001). Disappearing dividends: changing firm characteristics or lower propensity to pay? Journal of Financial Economics, 60(1), 3-43.

Gugler, K., and B. B. Yurtoglu. (2003). Corporate Governance and Dividend Pay-Out Policy in Germany. European Economic Review, 47, pp 731-758.

Jahankhany, Ali and ghorbani, Saeed. (2004). Identify and explain factors effect on dividend policy in Tehran Stock Exchange. Financial Research Journal in Iran, No. 20, pp. 27-48.

Jayesh Kumar. (2003). Ownership Structure and Dividend Payout Policy in India. Indira Gandhi Institute of Development Research, November. 
Kafash, Mohammad. (2009). The effect of ownership structure on firm performance in Tehran Stock Exchange. The Iranian accounting and auditing review, Spring, No. 55, p. 51-67.

Kimie Harada and Pascal Nguyen. (2003). Ownership concentration, agency conflicts and dividend policy in Japan. Journal of Finance, Vol. 55, Pp. 1-33.

Kouki .Mondher and Guizani Moncef. (2009). Ownership Structure and Dividend Policy Evidence from the Tunisian Exchange market. Eurojournals Publishing, Inc. 2009. [Online] Available: http://www.eurojournals.com.

La Porta, R., F. Lopez-de-Silanes, A. Shleifer and R.W. Vishny. (2000). Agency Problems and dividend policies around the world. Journal of Finance, 55(1), 1-13.

Lintner, john. (1956). Security prices, risk and maximal gains from diversification. Journal of finance, 20(4), pp.587-615.

Miller and Modigliani. (1961). Why individual investors want dividends. Journal of Corporate Finance, Vol. 12, Issue 1, December 2005, Pp. 121-158.

Mohammad Amidu and Joshuo Abor. (2006). Determinants of dividend payout ratios in Ghana. Journal of Risk Finance, Vol. 7, No. 2, pp. 136-145.

Mondher Kouki. (2009). Ownership Structure and Dividend Policy Evidence from Tunisian Market. European Journal of Scientific Research, Vol. 25, No. 1, pp.42-53.

Omneya Abdelsalam, Ahmed El-Masry, Sabri Elsegini. (2008). Board composition, ownership structure and dividend policies in an emerging market, Further evidence from CASE 50. Managerial Finance, Vol. 34, No. 12, pp. 953-964.

Qiang Li and Guoliang Huang. (2004). Influence of Institutional Ownership on Cash Dividend Policy of China Listed Companies. The Sixth Wuhan International Conference on E-Business International Finance Track, China.

Ravi Jain. (2007). Institutional and individual investor preferences for dividends and share repurchases. Journal of Economics and Business, Vol. 59, pp. 406-429.

Rozeff, M.S.. (1982). Growth, beta and agency costs as determinants of dividend payout Ratios. Journal of Financial Research, 5(3), 249-259.

Yaniv Grinstein and Roni Michaely. (2005). Institutional Holdings and Payout Policy. The Journal of Finance, Vol. 60, pp. 1389-1426.

Table 1. Description of variables

\begin{tabular}{|l|l|l|}
\hline Variables & \multicolumn{1}{|c|}{ Proxies } & \multicolumn{1}{c|}{ Calculations } \\
\hline POR & Payout Ratio & dividend per share/earnings per share \\
\hline OS & Ownership Structure & \\
\hline BIG & largest shareholder & percentage of shares owned by the largest shareholder \\
\hline INST & institutional shareholders & percentage of shares owned by the institutional shareholders \\
\hline INDV & individual shareholders & percentage of shares owned by the individual shareholders \\
\hline 5BIG & 5 largest shareholders & percentage of shares owned by the 5largest shareholders \\
\hline E & Earnings Per Share & dividing net profit by the common stock \\
\hline SG & Growth rate of sales & Annual change in the firm's total sales. \\
\hline CS & Size of the firm & multiply shares number of firms by market price of any shares \\
\hline
\end{tabular}


Table 2. Sample firms by industry

\begin{tabular}{|c|l|c|c|}
\hline group & \multicolumn{1}{|c|}{ Industry } & Number of firms & Percent \\
\hline 1 & Machinery, vehicles and parts & 11 & $28 \%$ \\
\hline 2 & food and drug & 14 & $35 \%$ \\
\hline 3 & chemical, plastic and cellulose & 8 & $21 \%$ \\
\hline 4 & Steel and cement & 5 & $11 \%$ \\
\hline 5 & Miscellaneous & 3 & $5 \%$ \\
\hline Total & & 41 & $100 \%$ \\
\hline
\end{tabular}

Table 3. Descriptive statistics

\begin{tabular}{|l|c|c|c|c|c|c|c|c|}
\hline Items & POR & BIG & INST & INDV & 5BIG & E & SG & CS \\
\hline Range & 37.13 & 74.36 & 92.38 & 81.73 & 63.03 & 4232.8 & 21.03 & 49638492.8 \\
Mean & 75.89 & 46.67 & 79.96 & 8.24 & 75.64 & 1366.43 & 18.29 & 9862715.6 \\
Maximum & 92.62 & 83.09 & 97.03 & 81.73 & 96.89 & 4286.00 & 28.39 & 4973712 \\
Minimum & 55.49 & 8.76 & 4.65 & 0.00 & 33.86 & 53.20 & 7.36 & 98627.16 \\
Std. Dev. & 11.47 & 16.82 & 23.46 & 22.14 & 14.06 & 839.80 & 5.46 & 11483645.9 \\
N & 41 & 41 & 41 & 41 & 41 & 41 & 41 & 41 \\
\hline
\end{tabular}

Table 4. Regression results of the hypotheses

\begin{tabular}{|c|c|c|c|c|c|c|c|}
\hline Hypotheses & variables & coefficients & t-value & significance & $\mathbf{F}$ & significance & $\begin{array}{c}\text { Adjuste } \\
\text { d R R }^{2}\end{array}$ \\
\hline \multirow{4}{*}{ First } & BIG & 0.101 & 0.951 & 0.348 & \multirow{4}{*}{1.969} & \multirow{4}{*}{0.120} & \multirow{4}{*}{0.088} \\
\hline & $\mathbf{E}$ & 0.004 & 1.725 & 0.093 & & & \\
\hline & SG & 0.468 & 1.417 & 0.165 & & & \\
\hline & CS & 0.00 & -0.078 & 0.939 & & & \\
\hline \multirow{4}{*}{ Second } & 5BIG & 0.25 & 2.074 & 0.045 & \multirow{4}{*}{2.978} & \multirow{4}{*}{0.032} & \multirow{4}{*}{0.165} \\
\hline & $\mathbf{E}$ & 0.003 & 1.68 & 0.101 & & & \\
\hline & SG & 0.594 & 1.86 & 0.071 & & & \\
\hline & CS & 0.00 & -0.122 & 0.904 & & & \\
\hline \multirow{4}{*}{ Third } & INST & 0.182 & 2.56 & 0.015 & \multirow{4}{*}{3.652} & \multirow{4}{*}{0.013} & \multirow{4}{*}{0.21} \\
\hline & $\mathbf{E}$ & 0.003 & 1.42 & 0.162 & & & \\
\hline & SG & 0.485 & 1.58 & 0.122 & & & \\
\hline & $\mathrm{CS}$ & 0.00 & -0.667 & 0.509 & & & \\
\hline \multirow{4}{*}{ Fourth } & INDV & -0.186 & -2.372 & 0.023 & \multirow{4}{*}{3.372} & \multirow{4}{*}{0.019} & \multirow{4}{*}{0.192} \\
\hline & $\mathbf{E}$ & 0.003 & 1.324 & 0.194 & & & \\
\hline & SG & 0.482 & 1.375 & 0.178 & & & \\
\hline & $\mathrm{CS}$ & 0.00 & -0.707 & 0.484 & & & \\
\hline
\end{tabular}

$1-\mathrm{F}$ value is found to be significant at $5 \%$ level of significance suggesting overall applicability of the existing model. 